\title{
GIFTS AND ACQUISITIONS
}

\section{Rare Eighteenth Century New Jersey Imprints}

Three significant eighteenth-century New Jersey imprints were acquired by the Library through the much publicized and longawaited Thomas W. Streeter sale, held at the Parke-Bernet Galleries in April. Two of these items were secured by means of the William Allen Chapman, C. H. Wilhelm, and Proprietors' funds. A third was purchased by a friend of the Library and past donor, Philip D. Sang, who presented it as a gift.

Most important is a 1723 edition of New Jersey laws printed at Perth Amboy by William Bradford (Evans, 2463) and believed to be the first New Jersey imprint. It is treated elsewhere in this issue. A much later imprint, though one of equal rarity as well as of particular value to the colonialist, is a folio edition of the West Jersey Proprietors' tract: An Address, from the Council of Proprietors of the Western Division of New Jersey, to the Occupiers of the Lands within the Angle, believed to be printed at Burlington, N.J., in I795. It is not listed in Evans, Sabin or the American Imprints Inventory. A I 2 mo. edition, also Burlington, I 795 (Evans, 28773), is already in the Library's rare book collection. The third Streeter sale item, that acquired through $\mathrm{Mr}$. Sang, is a 1787 edition of the United States Constitution. The sixteen page tract, published in Trenton by Isaac Collins, bears the title The Constitution of the United States of America. A greed to in Convention, at Philadelphia, September 17, 1787 (Evans, 20798). It is the first publication of the document to come from a New Jersey press.

Among other significant early imprints acquired by the Library over the past several months are the following: Die Löblich Bruderschafft zum Leicht Schiff [n.p.], I6I 7; The History of the Parliament of England: which began November the third, M.DC.XL. by Thomas May, London, 1647 (Wing, Mi4Io); Negotiations de Paix de Messieurs les Electeurs de Mayence et de Coloigne faites a Francfort par Leurs Altesses Electorales, Paris, I658; Idea de un Principe Politico Christiano Representada en cien Empresas by Diego de Saavedra Fajardo, Amsterdam, I664; Markham's Master- 
Piece: Containing all knowledge belonging to the Smith, Farrier, or Horse-Leech by Gervas Markham, London, I668 (Wing, M662); Les Delices de L'Esprit. Dialogues by Saint Sorlin J. Desmarets, Paris, I 676; Reflexions sur les Memoires pour les Ambassadeurs, et Response au Ministre Prisonnier by Fernando Galardi, Ville-Franche, I677; Fifty Comedies and Tragedies by Francis Beaumont and John Fletcher, London, I679 (Wing, Bi 582);An Examination of the Connecticut Claim to Lands in Pennsylvania by William Smith, Philadelphia, I774 (Evans, I3629); The Politician's Pocket Companion, Morristown [N.J.], I804 (Shaw \& Shoemaker, 7080).

\section{Manuscripts}

\section{Papers of a New Jersey Country Doctor}

"Dr. William Johnson, Wishing to establish himself at the White-House Village in the County of Hunterdon, respectfully solicits the patronage of the inhabitants of that place and its vicinity, in the line of his profession. In offering himself as a candidate for public favour, Dr. Johnson thinks it right to state that he has devoted several years of assiduous application to the study of medicine under the superintendance of an eminent physician, has attended the lectures at Philadelphia, in the various departments of his profession, and has paid particular attention to the extensive and judicious practice of Dr. Rush and Physick, in the Pennsylvania Hospital.

Dr. Johnson can produce the most unexceptionable testimonials of his character both as a man and a physician.

White-House Village, July i 8, i 8 i I"

The appearance of this printed announcement throughout Readington Township signalled the start of a medical practice which flourished for over fifty years. William Johnson ( I 789-1 867), son of Thomas P. and Mary (Stockton) Johnson of Princeton, N.J., began the study of medicine with Princeton physician John Van Cleve. Formal educational training came later at the Pennsylvania University College of Medicine, which granted him an M.D. in I 8 I I .

Although he chose to set up practice in a rural area, Dr. Johnson was no ordinary country practitioner. He compiled copious case histories, and recorded his medical observations and hypotheses; all of these served to guide him in the treatment of the sick. Meanwhile, 
his skill and genuine concern and attentiveness for his patients earned him a wide reputation, and he was much sought after both as healer and teacher. Many of Dr. Johnson's observations and thoughts regarding the practice of medicine found their way into print. He was a frequent contributor to American medical journals, and some of his articles were copied abroad.

The story of this uniquely qualified man of medicine, and, indeed, the story of the practice of medicine generally in nineteenth century New Jersey, are reflected in his papers, which have come to the Library over the years. A recent addition, presented by Mrs. Elizabeth L. Ripton, consists of personal and professional correspondence, I 810 , I 81 I ; notes kept during study and internship periods, I 810 , I 8 I I ; case histories, I 848 , I 853 , I 857 ; medical observations, assertions and hypotheses, ca. I845-I $85 \mathrm{I}$; vaccine register, I 848 ; speeches, lectures, I845, 1848; accounts, 18 12, 18 16; also the abovecited printed announcement, I 8 I I.

Other manuscript acquisitions include a collection of papers of Boston author Charles Felton Pidgin relating to the life and career of Aaron Burr, Vice President of the United States, I 80I-I 804. The materials represent the accumulated research data of the author and consist entirely of bibliographical references, holograph and typescript historical and biographical sketches, and printed extracts. The papers were a gift of Walter Goldwater. Mr. Goldwater also presented a small lot of New Jersey Communist Party records, I937I939, consisting of mimeographed reports, resolutions, convention proceedings, party literature, and items concerning state and local (Hudson County, N.J.) politics.

A first deposit of the records of the Free Acres Association of Berkeley Heights, N.J., a community established in I $9 \mathrm{IO}$, and based on the single tax theories of Henry George, was received from the association, in part through the good offices of Mr. Spencer Brodney. Included are minutes, I9IO-I935, business correspondence, I930I935, historical and biographical sketches, descriptive literature, photographs and printed miscellany. Mr. Brodney also added substantially to his own personal papers already in the Library. Free Acres materials make up a good share of this new accession, which 
also includes papers relating to the publication of Current History and Events magazines, I925-1948, of which Mr. Brodney was editor.

Papers of the Honorable Joseph S. Frelinghuysen, United States Senator from New Jersey, I9I6-1923, came as a bequest from the estate of Mrs. Joseph S. Frelinghuysen. Personal and political scrapbooks, I 898-I 900, form the bulk of the acquisition; however there is also a small but illuminating group of letters and documents bearing on Frelinghuysen's military service in the Spanish-American War. These new items have been absorbed into the Library's Joseph S. Frelinghuysen Papers.

Dr. Monroe Berkowitz, Department of Economics, Rutgers University, presented his files of Labor-Management arbitration case records, I948-1965. Dr. Robert J. Alexander of the same department has added substantially to his papers relating to Latin America already in the Library. Papers of the Isaac Howells family of Warren County, N.J., I 806-I 84I, chiefly letters from family members in Canada and estate inventories and accounts of the William Shaver, Jr. family, also of Warren County, were donated by Horace B. Howell, through the late Helen P. Alleman. Papers of John A. Powelson, Somerset County, N.J., came as a gift from Jennie Estelle and Lillian Alice Wikoff through E. Parker Hayden, Jr. Included are personal accounts, I 753-I 822; family letters, i 855 -I $89 \mathrm{I}$; Van Doren family letters, I 806-I 8 I 3 ; and genealogical notes and photographs, I866-I925, of the Powelson, Van Doren and Van Nest families. From Abram V. N. Powelson, also through Mr. Hayden, the Library has received Bedminster Township (Somerset County), N.J. school district records (attendance, rosters, board minutes, etc.), I 858-1893, and Van Doren and Van Deveer family items, i 808, 1829 .

Anthony S. Nicolosi 